\title{
1. Internet transactions and activities
}

\author{
Peter Stone
}

\section{INTRODUCTION}

Although the Internet has now been available for use by the general public for about 20 years, it is only in the last few years that the European Court has begun to address questions of EU private international law which relate to obligations arising from transactions and activities conducted by means of the Internet. A substantial body of case-law in which the European Court has addressed such questions now exists. In this chapter the said case-law will be examined with a view to establishing general principles which may be applicable to questions not yet specifically addressed, and to identifying issues on which the position remains unclear.

The principal EU legislative measures relevant to private international law in relation to Internet transactions and activities are the Brussels I Regulation on Jurisdiction and the Recognition and Enforcement of Judgments in Civil and Commercial Matters; ${ }^{1}$ the Rome I Regulation on the Law Applicable to Contractual Obligations; ${ }^{2}$ the Rome II Regulation on the Law Applicable to Non-contractual Obligations; ${ }^{3}$ and EC Directive

1 Two versions of the Brussels I Regulation exist. The revised version takes the form of EU Regulation 1215/2012, [2012] OJ L351/1, which became applicable on 10th January 2015. This has replaced the original version, EC Regulation 44/2001, [2001] OJ L12/1. In general the changes made by the revised version are not important in the context of the specific problems relating to Internet transactions and activities, though the relevant provisions have been renumbered. In this chapter reference will normally be made to the revised version.

2 EC Regulation 593/2008, [2008] OJ L177/6. This replaced the Rome Convention of 19th June 1980 on the Law Applicable to Contractual Obligations, [1998] OJ C27/34. The Rome I Regulation became applicable on 17th December 2009 in the then Member States other than Denmark in respect of contracts concluded after that date, and on 1st July 2013 in Croatia.

3 EC Regulation 864/2007, [2007] OJ L199/40. It became applicable on 11th January 2009 in the then Member States other than Denmark in respect of events occurring after that date, and on 1st July 2013 in Croatia. 


\section{Research handbook on EU private international law}

2000/31 on Electronic Commerce. ${ }^{4}$ The Brussels I Regulation deals with the international jurisdiction of the courts of the Member States to entertain proceedings brought before them, ${ }^{5}$ while the Rome I Regulation and the Rome II Regulation deal with the ascertainment of the law applicable by the courts of the Member States in the determination of the merits of a dispute. But similar concepts are used by the three Regulations, and Recital 7 to the Rome I and Rome II Regulations make it clear that such concepts should normally receive a similar interpretation in the three Regulations. The Directive on Electronic Commerce contains provisions which in certain circumstances give an Internet service provider the benefit of the law of the Member State in which it is established, so as to override the choice-of-law rules otherwise applicable under the Regulations.

It is convenient first to consider two general principles which have emerged from the case-law of the European Court, and then to examine in turn contractual, tortious and restitutionary claims.

\section{TWO GENERAL PRINCIPLES}

Two general principles, applicable in connection with most issues arising under EU private international law which involve Internet transactions or activities, have emerged from the case-law of the European Court. The first is that the location of a server on the Internet through which a person enters into or performs transactions or engages in activities, for example by operating a webpage on the server, is not an important connection for the purposes of private international law, whether in the context of judicial jurisdiction or of choice of law. Rather the person's role in such transactions or activities should be regarded as connected with a residence or establishment of the person in question, ascertained in the same way as in the case of transactions or activities not involving the Internet. The principle is recognised by Article 2(c) of the Directive on Electronic Commerce, which specifies that presence and use of the technical means and technologies required to provide an information society service do

4 EC Directive 2000/31 on Certain Legal Aspects of Information Society Services, in particular Electronic Commerce, in the Internal Market, [2000] OJ L178/1.

5 The Brussels I Regulation also provides for the recognition and enforcement in a Member State of judgments given in other Member States, but these provisions do not give rise to special problems in cases involving Internet transactions and activities, and will not be considered in this chapter. 
not, in themselves, constitute an establishment of the service provider. Similarly its Recital 19 explains that the place of establishment of a company providing services via an Internet website is not the place at which the technology supporting its website is located or the place at which its website is accessible, but the place where it pursues its economic activity.

The principle that the location of technological hardware (such as an Internet server) is immaterial as a connecting factor was also accepted by the European Court in Wintersteiger $v$ Products $4 U,{ }^{6}$ which addressed the operation of the judicial jurisdiction conferred by Article 7(2) of the Brussels I Regulation on the courts for the place of the defendant's wrongful conduct, in the context of a claim for the infringement of a trade mark registered in one Member State by an advertiser's use of a keyword on a search engine operating under a country-specific top-level domain of another Member State. The European Court explained that, although the technical display process by the advertiser is activated, ultimately, on a server belonging to the operator of the search engine used by the advertiser, the place of establishment of that server could not, in view of the objective of foreseeability, and by reason of its uncertain location, be considered to be the place of the wrongful conduct for the purpose of Article 7(2). Rather, since it is a definite and identifiable place, and is therefore likely to facilitate the taking of evidence and the conduct of the proceedings, the place of establishment of the advertiser must be treated as the place of its wrongful conduct.

The second general principle which has emerged from the case-law of the European Court is that it is unnecessary under EU private international law, in order to enable the courts of a Member State to have judicial jurisdiction over a claim relating to an Internet transaction or activity, or to make the law of a country applicable to the merits of such a claim, for the defendant to have intentionally targeted the public in the relevant country. The non-existence of any such requirement was established by the European Court in the context of claims for the infringement of national intellectual property rights (such as a registered trade mark or a copyright), ${ }^{7}$ but it seems natural to generalise the principle as applicable to all provisions of EU private international law which do not

\footnotetext{
6 Case C-523/10, [2013] Bus LR 150.

7 See Case C-523/10: Wintersteiger v Products $4 U$ [2013] Bus LR 150; Case C-170/12: Pinckney v Mediatech, 3rd October 2013; and Case C-441/13: Hejduk v EnergieAgentur.NRW, 22nd January 2015. See also Case C-387/12: Hi Hotel $v$ Spoering [2014] All ER (D) 36 (Apr); and Case C-360/12: Coty v First Note Perfumes, 5th June 2014.
} 


\section{Research handbook on EU private international law}

explicitly provide otherwise. Thus an exception exists in the cases of claims based on a consumer contract, in view of the explicit use in the relevant provisions of both the Brussels I Regulation and the Rome I Regulation of the concept of directing activities by the supplier to the country of the consumer's domicile or habitual residence. ${ }^{8}$

\section{CONTRACTUAL CLAIMS}

With regard to the operation of EU private international law in respect of claims relating to contracts which were concluded or to be performed by means of the Internet, it is necessary to distinguish between ordinary contracts, consumer contracts, and other special types of contract. It is also necessary to consider the potential impact of Directive 2000/31 on Electronic Commerce.

\section{Ordinary Contracts}

As regards judicial jurisdiction under the Brussels I Regulation, any type of contract counts as an ordinary contract, except those for which special provision is made by the Regulation and those which are excluded from its scope. The types of contract which do not count as ordinary contracts for this purpose are insurance contracts; certain consumer contracts; employment contracts; tenancies of land; and contracts relating to family matters or succession on death. ${ }^{9}$ As regards choice of law under the Rome I Regulation, any type of contract counts as an ordinary contract, except those for which special provision is made by the Regulation and those which are excluded from its scope. The types of contract which do not count as ordinary contracts for this purpose are contracts of carriage; certain consumer contracts; certain insurance contracts; employment contracts; tenancies of land; contracts relating to family matters; negotiable instruments; and contracts governed by company law. ${ }^{10}$

In the case of an ordinary contract, no particular problem in relation to judicial jurisdiction appears to arise from the fact that the contract was negotiated or concluded by means of the Internet. For the jurisdictional rules specified by the Brussels I Regulation refer to the defendant's domicile or secondary establishment, the place of performance of a

8 See Cases C-585/08 and C-144/09: Pammer v Reederei Karl Schlüter and Hotel Alpenhof v Heller [2010] ECR I-12527.

9 See Articles 1(2), 10-23 and 24(1) of the Brussels I Regulation.

10 See Articles 1(2), 4(1)(c)-(d) and 5-8 of the Rome I Regulation. 
contractual obligation, and submission by agreement or appearance. ${ }^{11}$ But problems may arise from the fact that the contract was for services to be supplied by means of the Internet; as where the contract is for the provision of access to an online database, or for the supply of code or data to be downloaded. For Article 7(1)(b)(ii) confers jurisdiction over a defendant who is domiciled in one Member State, in the case of a contract for the provision of services, on the courts of another Member State for the place where, under the contract, the services were provided or should have been provided.

The rulings of the European Court in cases not involving supply through the Internet establish that Article 7(1)(b)(ii) must be understood as referring primarily to the courts for the place or places at which the main provision of services is to be carried out, as indicated in the contract. ${ }^{12}$ If no such place can be ascertained, these rulings indicate that reference must next be made to the place where the characteristic performer (such as the agent, in the case of a commercial agency contract; or the distributor, in the case of an exclusive distribution agreement) in fact for the most part carried out his activities in the performance of the contract, provided that the provision of services in that place was not contrary to the provisions of the contract. And as a last resort reference must be made to the domicile of the characteristic performer. ${ }^{13}$

The operation of these rulings in cases where the contract is for the provision of access to an online database, or for the supply of code or data (such as a file containing a computer program, or a digitised literary, musical or artistic work or a phonogram or videogram, to be downloaded by the recipient), seems less than clear. It seems likely that Article 7(1)(b)(ii) will usually be treated as referring to a residence of the supplier from which the server containing the database, code or data is administered, except perhaps where the contract identifies the place from

11 See Articles 4, 7(1), 25 and 26 of the Regulation.

12 See Case C-204/08: Rehder v Air Baltic [2009] ECR I-6073, which involved a contract for the carriage of a passenger by air, and recognised the jurisdiction of both the court for the place of departure of the aircraft, and that of the court for the place of arrival of the aircraft, as specified in the contract; and Case C-19/09: Wood Floor Solutions Andreas Domberger GmbH v Silva Trade SA [2010] ECR I-2121, which involved a commercial agency contract.

13 See Case C-19/09: Wood Floor Solutions Andreas Domberger GmbH $v$ Silva Trade SA [2010] ECR I-2121; and Case C-9/12: Corman-Collins v La Maison du Whisky [2014] QB 431. 
which the customer is to access the database, or to which the code or data file is to be downloaded.

In the case of an ordinary contract, no particular problem in relation to choice of the applicable law appears to arise from the fact the contract was negotiated or concluded by means of the Internet, nor from the fact that the contract was for services to be supplied by means of the Internet (as where the contract is for the provision of access to an online database, or for the supply of code or data to be downloaded). For the choice-oflaw rules specified by Articles 3 and 4 of the Rome I Regulation refer to an express or implied choice of law by the parties; to the habitual residence of the characteristic performer; to the law governing a market in financial instruments; and to the country of closest connection.

A possible exception concerns an online auction of goods, for Article $4(1)(\mathrm{g})$ provides a rebuttable presumption that, in the absence of an express or implied choice of law by the parties, a contract for the sale of goods by auction will be governed by the law of the country where the auction takes place, if such a place can be determined. In the case of an online auction, it seems appropriate to treat the auction as taking place at the residence of the auctioneer from which the auction is organised, at least if the location of the office in question was made apparent to the potential bidders prior to the holding of the auction. As a last resort, one may be forced to treat the location of an online auction as undeterminable, so that the rebuttable presumption in favour of the seller's residence (which applies to non-auction sales of goods) becomes applicable.

\section{Consumer Contracts}

As regards consumer contracts, in general both Articles 17-19 of the Brussels I Regulation and Article 6 of the Rome I Regulation confine the protection which they provide for the consumer as a weaker party to cases where the supplier either pursues commercial or professional activities in the consumer's country, or (by any means) directs such activities to that country or to several countries including that country, and (in either case) the contract falls within the scope of such activities. As regards judicial jurisdiction, the Brussels I Regulation treats the consumer's domicile as his country, and further requires that his domicile must be located in a Member State. ${ }^{14}$ As regards choice of law, the Rome I Regulation treats the country of the consumer's habitual residence as his country, and provides protection even if that country is not a Member

14 See Article 17(1)(c) of the Brussels I Regulation. 
State. ${ }^{15}$ By way of exception, as regards judicial jurisdiction, Article 17(1)(a) and (b) of the Brussels I Regulation extend the protection to contracts by which a consumer obtains credit in connection with the sale of goods, regardless of whether the supplier had pursued activities in or directed activities to the consumer's country; but no such extension is made by the Rome I Regulation. In any event under both Regulations the concept of directing activities to the consumer's country plays a crucial role in determining the scope of the provisions protecting consumers in relation to transactions involving the Internet.

In a series of cases the European Court has addressed the concept of directing activities to the consumer's country for the purpose of judicial jurisdiction under Article 17(1)(c) of the Brussels I Regulation, in the context of activities on the Internet. In Pammer v Reederei Karl Schlüter and Hotel Alpenhof $v$ Heller, ${ }^{16}$ it ruled that, in order to determine whether a trader whose activity is presented on its website can be considered to be directing its activity to the Member State of the consumer's domicile, it should be ascertained whether it is apparent from the website and the trader's overall activity that, before the conclusion of any contract with the consumer, the trader envisaged doing business with consumers domiciled in one or more Member States, including that of the domicile of the consumer in question, in the sense that it was minded to conclude contracts with them.

In Pammer the European Court also provided a non-exhaustive list of matters which are capable of constituting evidence that the trader's activity is directed to the Member State of the consumer's domicile: the international nature of the activity; the mention of itineraries from other Member States for going to the place where the trader is established; the use of a language or currency other than those generally used in the Member State in which the trader is established, with the possibility of making and confirming a reservation in that other language; the mention of telephone numbers with an international code; the outlay of expenditure on an Internet referencing service in order to facilitate access to the trader's site by consumers domiciled in other Member States; the use of a top-level domain name other than that of the Member State in which the trader is established; and the mention of an international clientele composed of customers domiciled in various Member States. It added that the mere accessibility of the trader's website in the Member State in which the consumer is domiciled is insufficient, as is the mention of an

\footnotetext{
15 See Article 6(1) of the Rome I Regulation.

16 Cases C-585/08 and C-144/09, [2010] ECR I-12527.
} 
email address and other contact details, and the use of a language and currency generally used in the Member State in which the trader is established.

In Mühlleitner $v$ Yusufi, ${ }^{17}$ the European Court ruled that Article 17(1)(c) of the Brussels I Regulation does not require the contract between the consumer and the trader to be concluded at a distance. Thus the protective provisions may apply where the contract has been concluded during a visit by the consumer to the supplier's premises, after earlier communications by Internet and telephone. In Emrek $v$ Sabranovic, ${ }^{18}$ it ruled that Article 17(1)(c) does not require the existence of a causal link between the means employed to direct the commercial or professional activity to the Member State of the consumer's domicile, such as a website, and the conclusion of the contract with the consumer; but that the existence of such a causal link constitutes evidence of the connection between the contract and such activity. In Emrek the supplier, a used-car dealer, had directed activities abroad by means of his website, but the consumer had learned of the supplier's establishment, where the contract was concluded, not from the website but from acquaintances.

In Emrek the European Court also explained that the factors capable of constituting evidence of commercial activity directed to the Member State of the consumer's domicile include the establishment of contact at a distance; the conclusion of a consumer contract at a distance; the existence of a causal link between the means used to direct the commercial or professional activity to the Member State in which the consumer is domiciled, such as an Internet site, and the conclusion of the contract with that consumer; and the facts that a trader is established in a Member State close to the border with another Member State, in an urban area extending on both sides of the border (in casu, the towns of Spicheren in France and Sarrebruck in Germany), and that he uses a telephone number allocated by the other Member State, so as to enable potential clients domiciled there to save the cost of an international call. It emphasised that it is for the court seised to make an overall assessment of the circumstances in which the consumer contract at issue was concluded, in order to decide whether or not Article 17(1)(c) is applicable.

It may be inferred from these rulings that, in cases where a contract has been concluded by means of an order placed electronically by a consumer via a trader's website, the determination of whether the trader

17 Case C-190/11, [2012] All ER (D) 74 (Sep).

18 Case C-218/12, [2014] Bus LR 104. 
was directing activities to the country of the consumer's domicile by means of or including its website may require careful examination of the trader's website and its other activities, but the conclusion will rarely be reached that the trader was not directing activities to the consumer's country.

It seems clear that, with the substitution of references to the country of the consumer's habitual residence for the references to the Member State of his domicile, these rulings on directing activities for purposes of judicial jurisdiction under Article 17(1)(c) of the Brussels I Regulation are also applicable for the purposes of choice of law under Article 6(1) of the Rome I Regulation.

\section{Other Special Types of Contract}

As well as for consumer contracts, both the Brussels I Regulation and the Rome I Regulation make special provision for insurance contracts, employment contracts and tenancies of land. ${ }^{19}$ The Rome I Regulation also makes special provision for contracts for the carriage of goods or passengers. ${ }^{20}$ In general these provisions do not appear to give rise to particular difficulties in cases where the contract is negotiated or concluded or to be performed by means of the Internet. But the possibility of occasional problems cannot be entirely ruled out.

Thus, as regards judicial jurisdiction over insurance, one could envisage the possibility of difficulty in ascertaining the location of the harmful event, which may give rise to judicial jurisdiction under Article 12 of the Brussels I Regulation, where (for example) the insurance is of a website against malicious damage (such as a denial-of-service attack). Since general principles indicate that the physical location of a server involved should be regarded as unimportant, and the choice of this location by the operator of the website attacked seems unlikely to have any substantial connection with either the attack or the insurance, it seems appropriate to regard the harmful event as occurring at the residence of the operator of the server from which he administered the website.

As regards employment, one could envisage difficulties in ascertaining the place of habitual work, which is relevant to judicial jurisdiction under Article 21 of the Brussels I Regulation and to choice of law under Article 8 of the Rome I Regulation, in cases where (for example) the employee's work comprises the editing of entries on Wikipedia, and he is free to

19 See Articles 10-16, 20-23 and 24(1) of the Brussels I Regulation; and Articles 4(1)(c)-(d), 7 and 8 of the Rome I Regulation.

20 See Article 5. 
reside at and carry out the work from any place where there is an adequate Internet connection. In many cases of this kind it will no doubt be possible to ascertain the place of habitual work by reference to the employee's actual working activities, which will enable one to identify either his centre of activities, or the place where he carries out the majority of his activities. But, as a last resort, it may sometimes be necessary to accept that no place of habitual work can be ascertained, and to utilise the secondary reference made by these provisions to the location of the employer's establishment by which the employee was engaged..$^{21}$

\section{The Directive on Electronic Commerce}

As regards choice of law, the relationship of the Rome I Regulation with other European Union legislation is addressed by Article 23, which specifies that, with the exception of Article 7 (on insurance), the Regulation is not to prejudice the application of provisions of European Union law which, in relation to particular matters, lay down conflict rules relating to contractual obligations. In addition Recital 40 declares that the Regulation should not prejudice the application of other instruments laying down provisions designed to contribute to the proper functioning of the internal market, insofar as they cannot be applied in conjunction with the law designated by the rules of the Regulation. It further explains that the application of provisions of the applicable law designated by the rules of the Regulation should not restrict the free movement of goods and services as regulated by European Union instruments, such as Directive 2000/31 on Electronic Commerce. ${ }^{22}$

Article 3(1) of Directive 2000/31 requires each Member State to ensure that the information society services provided by a service provider established on its territory comply with the national provisions applicable in the Member State in question which fall within the co-ordinated field. Article 3(2) prohibits Member States, for reasons falling within the co-ordinated field, from restricting the freedom to provide information society services from another Member State. Article 1(4) specifies that the Directive does not establish additional rules on private international

21 See Case C-125/92: Mulox v Geels [1993] ECR I-4075; Case C-383/95: Rutten v Cross Medical [1997] ECR I-57; Case C-37/00: Weber v Universal Ogden Services [2002] ECR I-2013; Case C-29/10: Koelzsch v Luxembourg [2011] ECR I-1595; and Case C-384/10: Voogsgeerd v Navimer, 15th December 2011. None of these cases involved the Internet.

22 [2000] OJ L178/1. 
law, but Recital 23 explains that provisions of the applicable law designated by rules of private international law must not restrict the freedom to provide information society services as established in the Directive.

The effect of Article 3 of the Directive in relation to choice of law was addressed by the European Court in eDate Advertising $v X$ and Martinez $v M G N,{ }^{23}$ which involved an action for invasion of privacy brought in a German court by a German plaintiff against an Austrian defendant in respect of a publication on the defendant's website (in the at top-level domain). The European Court ruled that Article 3 of the Directive requires that, in relation to the co-ordinated field, Member States must ensure that the provider of an electronic commerce service is not made subject to stricter requirements than those provided for by the substantive law applicable in the Member State in which the service provider is established. It explained that Article 3 extends to the private law field, and puzzlingly denied that this interpretation made Article 3(1) into a rule of private international law.

Despite this ruling, it seems clear that Article 3 of the Directive cannot have any significant effect in the contractual field, in view of the exclusions specified by Article 3(3) and the associated Annex. These exclusions refer (inter alia) to the following fields: the freedom of the parties to choose the law applicable to their contract; contractual obligations concerning consumer contracts; various provisions on choice of law contained in EC Directives on insurance (now replaced by Article 7 of the Rome I Regulation); the formal validity of contracts creating or transferring rights in real estate, where such contracts are subject to mandatory formal requirements of the law of the Member State where the real estate is situated; and the permissibility of unsolicited commercial communications by electronic mail.

It also seems clear that Directive 2006/123 on Services in the Internal Market $^{24}$ cannot affect choice of law in respect of contracts. For Article 3(2) specifies that the Directive does not concern rules of private international law, in particular rules governing the law applicable to contractual and non-contractual obligations, including those which guarantee that consumers benefit from the protection granted to them by the consumer protection rules laid down in the consumer legislation in force in their Member State. Moreover Article 17(15) specifies that Article 16 (on freedom to provide services) does not apply to provisions regarding

\footnotetext{
23 Joined Cases C-509/09 and C-161/10, [2011] ECR I-10269.

24 [2006] OJ L376/36.
} 
contractual and non-contractual obligations, including the form of contracts, determined pursuant to the rules of private international law. And Recital 90 explains that contractual relations between the provider and the client, as well as between an employer and employee, should not be subject to the Directive; and that the applicable law regarding the contractual or non-contractual obligations of the provider should be determined by the rules of private international law.

\section{TORTIOUS CLAIMS}

\section{Judicial Jurisdiction}

As regards judicial jurisdiction, the Brussels I Regulation enables a claim in tort to be brought (at the plaintiff's choice) before the courts of the Member State in which the defendant is domiciled (under Article 4), or before the courts in another Member State for the place where the harmful event occurred or may occur (under Article 7(2)), or for the place where the defendant's secondary establishment from whose operations the dispute has arisen is located (under Article 7(5)).

In a series of cases the European Court has established that, for the purpose of Article 7(2), both the defendant's wrongful conduct and the initial injury to the plaintiff count as harmful events, and that, under Article 7(2), the plaintiff has the option of suing either at the place of the defendant's wrongful conduct or at the place of the plaintiff's initial injury, but not at the place where further loss occurred in consequence of the initial injury. ${ }^{25}$ But Article 7(2) does not confer jurisdiction by reference to the location of wrongful conduct, as distinct from that of the injury, over an alleged tortfeasor who has not acted within the forum territory, even if another tortfeasor, who is liable for the same damage, but is not a party to the action, has committed a wrongful act there. ${ }^{26}$

25 See Case 21/76: Bier v Mines de Potasse d'Alsace [1976] ECR 1735; Case 220/88: Dumez v Hessische Landesbank [1990] ECR I-49; Case C-364/93: Marinari v Lloyd's Bank [1995] ECR I-2719; Case C-51/97: Réunion Européenne v Spliethoff's Bevrachtingskantoor [1998] ECR I-6511; and Case C-168/ 02: Kronhofer v Maier [2004] ECR I-6009.

26 See Case C-228/11: Melzer v MF Global UK [2013] QB 1112; Case C-387/12: Hi Hotel v Spoering [2014] All ER (D) 36 (Apr); and Case C-360/12: Coty v First Note Perfumes, 5th June 2014. 
As regards torts committed by means of the Internet, the European Court has so far considered claims for defamation or invasion of privacy, and claims for infringement of intellectual property rights.

\section{Defamation and privacy}

With regard to defamation by newspaper article, the European Court ruled in Shevill v Presse Alliance ${ }^{27}$ that, for the purpose of Article 7(2) of the Brussels I Regulation, the publisher's establishment from which the libel was issued and put into circulation counts as the place of the wrongful conduct. Thus Article 7(2) enables the plaintiff to sue in the courts for that place, and those courts have jurisdiction to award damages for all the harm caused anywhere by the defamation. In addition, in enabling the plaintiff to sue at the place of injury, Article 7(2) confers jurisdiction on the courts of any Member State in which the newspaper was distributed and the victim claims to have suffered injury to his reputation, but such jurisdiction is limited to the harm caused in the forum State. The Shevill principles extend to a television broadcast. ${ }^{28}$

But in eDate Advertising $v X$ and Martinez $v M G N^{29}$ the European Court distinguished Shevill and laid down a new rule in respect of the operation of Article 7(2) in relation to claims for defamation or invasion of privacy by means of a publication on an Internet website. eDate involved an action for invasion of privacy brought in a German court by a German plaintiff against an Austrian defendant in respect of a publication on the defendant's website (in the at top-level domain). Martinez involved an action for invasion of privacy brought in a French court by a French plaintiff against an English defendant (the publisher of Sunday Mirror) in respect of a publication on the defendant's website (in the .uk top-level domain).

The European Court distinguished the placing online of content on a website from the regional distribution of media such as printed matter, mainly because of the ubiquity of content placed online, which reduces the usefulness of the criterion of distribution. It therefore ruled that, under Article 7(2), in the event of an alleged infringement of personality rights by means of content placed online on an Internet website, the person who considers that his rights have been infringed has the option of

27 Case C-68/93, [1995] ECR I-415.

28 See Ewins $v$ Carlton Television [1997] 2 ILRM 223 (Barr J), permitting an action in Ireland for a libel effected by means of a television broadcast transmitted from Ulster and received in Ireland, but limited to injury to reputation in Ireland.

29 Joined Cases C-509/09 and C-161/10, [2011] ECR I-10269. 
bringing an action for liability in respect of all the damage caused, either before the courts of the Member State in which the publisher of the content is established, or before the courts of the Member State in which the plaintiff's centre of interests is based. The plaintiff may also, instead of bringing an action for liability in respect of all the damage caused, bring his action before the courts of each Member State in the territory of which content placed online is or has been accessible, but those courts have jurisdiction only in respect of the damage caused in the territory of the forum State. It also explained that the place where a person has the centre of his interests corresponds in general to his habitual residence; but that a person may also have the centre of his interests in a Member State in which he does not habitually reside, insofar as other factors, such as the pursuit of a professional activity, may establish the existence of a particularly close link with that State.

It is clear that this ruling is very favourable to plaintiffs who complain of defamation or invasion of privacy by means of publication on the Internet. It enables a plaintiff to sue in any Member State which he chooses, at least in regard to injury sustained there, and could have a strong chilling effect on legitimate freedom of speech on the Internet. ${ }^{30}$ But it is also clear from other rulings (considered below) that it is only in cases of defamation and invasion of privacy that an approach so favourable to tort claimants has been adopted.

\section{Infringement of national intellectual property rights}

In a series of cases, ${ }^{31}$ some of which involved Internet activities, the European Court has addressed the operation of Article 7(2) of the

30 See Vick and MacPherson, Anglicising Defamation Law in the European Union (1996) 36 Virginia Journal of International Law 933.

31 See Case C-523/10: Wintersteiger v Products $4 U$ [2013] Bus LR 150; Case C-170/12: Pinckney v Mediatech, 3rd October 2013; Case C-387/12: Hi Hotel v Spoering [2014] All ER (D) 36 (Apr); and Case C-441/13: Hejduk v EnergieAgentur.NRW, 22nd January 2015. Wintersteiger involved an Austrian action for an alleged infringement, committed via the Internet, of an Austrian trade mark, consisting of the word 'Wintersteiger', registered for ski and snowboard servicing tools, and owned by an Austrian company. The alleged infringement arose from the registration by the defendant, a German company and a competitor, of the same word as a keyword on the search service provided by Google on its top-level domain for Germany. Pinckney involved a French action for copyright infringement, brought by a French composer of songs against an Austrian company in respect of compact discs which the defendant had manufactured in Austria, and which had subsequently been marketed by British companies through Internet sites which were accessible in France. Hi Hotel involved a 
Brussels I Regulation in respect of actions for the infringement of a specific intellectual property right (such as a patent, a copyright or a registered trade mark), created and governed by the law of a Member State.

These rulings have recognised the territorial character of such rights, and have established that Article 7(2) confers jurisdiction over such infringement actions on the courts of the Member State by which the intellectual property right relied on was created, as the courts for the place of injury, but that such jurisdiction is limited to damage caused within that State. Such jurisdiction extends to a defendant who did not himself commit an infringing act within the forum State, but whose act elsewhere led to the commission by another person of an infringing act within the forum State; as where the defendant supplied articles elsewhere to another person, who proceeded to market them, in breach of the intellectual property right, in the forum State. These rulings further establish that Article 7(2) also confers jurisdiction over such infringement actions on the courts of the Member State in which is located the defendant's establishment involved in the allegedly infringing activity, as the courts for the place of conduct.

These rulings have also established that jurisdiction under Article 7(2) is not dependent on the defendant's having intentionally targeted the public in the Member State in which the intellectual property right exists. Such targeting may be relevant to the existence of substantive liability for infringement, but not to judicial jurisdiction to entertain an action for alleged infringement. ${ }^{32}$ The European Court has also ruled that the same

German action for infringement of copyright in photographs against a French company which allegedly had made the photographs available in France to a German company, whose sister company had proceeded to distribute copies of them in Germany. Hejduk involved an Austrian action for infringement of copyright in photographs by making them available online through a webpage on the top-level domain for Germany.

32 On substantive requirements, see Case C-324/09: L'Oréal v eBay [2011] ECR I-6011, dealing with trade mark infringement by means of sales and advertising through an online marketplace; Case C-173/11: Football Dataco $v$ Sportradar [2012] All ER (D) 211 (Oct), dealing with infringement of the neighbouring right in a database under Directive 96/9, [1996] OJ L77/20; Case C-462/09: Stichting de Thuiskopie v Opus Supplies [2011] ECR I-5331, dealing with private copying levies under Article 5 of Directive 2001/29, [2001] OJ L167/10; and Case C-5/11: Donner [2012] All ER (D) 65 (Jul), dealing with copyright infringement under Article 4 of Directive 2001/29. 
principles apply to the operation of Article 7(2) in respect of claims under national law for torts such as unfair competition or passing-off. ${ }^{33}$

\section{Infringement of Union-wide intellectual property rights}

A different approach has however been adopted in relation to actions for infringement of a Union-wide intellectual property right (a Community trade mark, registered under EC Regulation 207/2009;34 a Community plant variety right, granted under EC Regulation 2100/94;35 or a Community design, registered or otherwise protected under EC Regulation $\left.6 / 2002^{36}\right)$.

Article 7(2) of the Brussels I Regulation does not apply to such actions. Instead each of the Regulations creating a Union-wide right itself confers jurisdiction on the courts of the Member State in which an infringing act has been committed or threatened, but only in respect of infringing acts committed in that State. ${ }^{37}$ In Coty v First Note Perfumes ${ }^{38}$ the European Court ruled that these provisions referring to the location of an infringing act confer jurisdiction solely on the courts of the Member State in which the defendant committed (or would, if he had carried out his threat, have committed) the alleged unlawful act. Thus they do not confer jurisdiction on German courts over a Belgian defendant who had sold and delivered an infringing product in Belgium to a German company, which had proceeded to resell the product in Germany.

These Regulations also provide a cascade of rules which confer general jurisdiction over infringement actions on the courts of a single specified Member State in respect of infringing acts committed anywhere within the European Union. Each rule is applied in turn, so that if (but only if) an earlier rule fails to provide a competent Member State, one proceeds to the next rule. The first of these rules refers to the courts of

33 See Case C-360/12: Coty v First Note Perfumes, 5th June 2014. This involved a German action for unfair competition in respect of perfume sold and delivered in Belgium by the defendant, a Belgian company, to a German company, which had proceeded to resell them in Germany.

34 Regulation 207/2009 on the Community trade mark, [2009] OJ L78/1; replacing Regulation 40/94, [1994] OJ L11/1. See Articles 94-98 of Regulation 207/2009.

35 Regulation 2100/94 on Community plant variety rights, [1994] OJ L227/1. See Articles 101-102 thereof.

36 Regulation 6/2002 on Community designs, [2002] OJ L3/1. See Articles 79-83 thereof.

37 See Articles 97(5) and 98(2) of Regulation 207/2009; Article 101(3) of Regulation 2100/94; and Articles 82(5) and 83(2) of Regulation 6/2002.

38 Case C-360/12, 5th June 2014. 
the Member State in which the defendant is domiciled. If the defendant is not domiciled within the European Union, the second rule refers to the courts of the Member State in which the defendant has an establishment. If the defendant is not domiciled and has no establishment within the European Union, the third rule refers to the courts of the Member State in which the plaintiff is domiciled. If the defendant is not domiciled and has no establishment within the European Union, and the plaintiff also is not domiciled within the European Union, the fourth rule refers to the courts of the Member State in which the plaintiff has an establishment. ${ }^{39}$ If neither the defendant nor the plaintiff is domiciled or has an establishment within the European Union, the final rule confers jurisdiction on the Spanish courts, in the case of a trade mark or a design right; or on the French courts, in the case of a plant variety right. ${ }^{40}$ There is no apparent reason to suppose that these rules on general jurisdiction will raise any particular problems in relation to Internet activities.

\section{Other types of tort}

Problems concerning judicial jurisdiction over tort claims involving Internet activities may also arise in respect of other types of tort, which have not yet been specifically addressed by the European Court. In particular, there is a substantial English case-law dealing with tortious claims in respect of false statements made by the defendant and relied on by the plaintiff, giving rise to liability for deceit, negligent misrepresentation or conspiracy to defraud. ${ }^{41}$ This line of English cases establishes that Article 7(2) of the Brussels I Regulation confers jurisdiction on the court for the place where the statement was issued by the defendant, for example the place at which he spoke on the telephone or from which he

39 See Articles 97(1)-(2) and 98(1) of Regulation 207/2009; Article 101(2) of Regulation 2100/94; and Articles 82(1)-(2) and 83(1) of Regulation 6/2002.

40 See Article 97(3) of Regulation 207/2009; Article 82(3) of Regulation 6/2002; and Article 101(2)(c) of Regulation 2100/94.

41 See Domicrest v Swiss Bank [1999] QB 548 (Rix J); Dunhill v Diffusion Internationale de Maroquinerie de Prestige [2002] ILPr 13 (Rokison QC); Raiffeisen Zentralbank v National Bank of Greece [1999] 1 Lloyd's Rep 408 (Tuckey J); Vilona v Delorenzi [2002] EWHC 3016 (Comm) (Cresswell J); ABCI $v$ Banque Franco-Tunisienne [2003] 2 Lloyd's Rep 146 (CA); Bank of TokyoMitsubishi v Baskan Gida [2004] ILPr 26 (Lawrence Collins J); London Helicopters v Heliportugal [2006] 1 All ER (Comm) 595 (Simon J); and Crucial Music v Klondyke Management [2008] 1 All ER (Comm) 642 (Livesey QC). Cf. Maple Leaf v Rouvroy [2009] EWHC 257 (Comm) (Andrew Smith J), and Sunderland Marine Mutual Insurance v Wiseman [2007] 2 All ER (Comm) 937 (Langley J). 
sent a letter by post (as the place of the wrongful conduct); and on the court for a place at which goods were delivered or accepted, or at or from which money was paid, by the plaintiff as a result of his reliance on the statement (as the place of injury). But Article 7(2) does not confer jurisdiction on the court for a place where the plaintiff merely received the statement and/or acted in reliance thereon by taking a decision or giving an instruction or entering into a contract leading to a delivery or payment elsewhere. In none of these English cases was the false statement communicated by the defendant to the plaintiff by means of the Internet, but there is no reason to doubt that the same principles are applicable where, for example, the false statement was sent by email, rather than communicated by telephone or post.

There is also English case-law dealing with the application of Article $7(2)$ in respect of torts involving the misappropriation of corporate funds by an officer of the company, in which reference is made to the location of a bank account to or from which funds are transferred. ${ }^{42}$ Thus it is possible that in this context problems could arise in ascertaining the location of a relevant bank account, in cases where the account is operated by means of the Internet rather than through a traditional branch office of the bank. Presumably the online bank account will be regarded as located at the office of the bank by which the online banking service is administered.

\section{Choice of the Applicable Law}

\section{The Rome II Regulation}

The main choice-of-law rules, which apply to most types of tort, are specified by Article 4 of the Rome II Regulation, which refers to the place of initial injury, the habitual residence of both parties, and the country of closest connection. It seems clear that for this purpose the place of initial injury must be ascertained in the same way as under Article 7(2) of the Brussels I Regulation. Thus any problems concerning the place of initial injury in relation to Internet activities which have not yet been resolved under Article 7(2) of the Brussels I Regulation may equally arise under Article 4 of the Rome II Regulation. Otherwise it seems that in general neither Article 4 of the Rome II Regulation, nor the specific provisions made by Articles 5, 7 and 9 of that Regulation for torts involving product liability, environmental damage or industrial

42 See Cronos Containers v Palatin [2003] 2 Lloyd's Rep 489 (Morison J). 
action, is likely to give rise to particular problems in cases involving the Internet.

Article 6(1) of the Rome II Regulation, in dealing with unfair competition not exclusively affecting the interests of a specific competitor, refers to the law of the country where competitive relations or the collective interests of consumers are, or are likely to be, affected. It seems that Article 6(1) is designed to refer to the law of the location of the market which is directly affected, and that this law will also govern liability for consequential losses sustained elsewhere. But, as the Explanatory Memorandum recognises, ${ }^{43}$ there may be direct effects in more than one market, resulting in the distributive application of the laws involved. Difficulties could arise in identifying the relevant market in cases where the defendant's activity on the Internet affects competitors or customers in numerous countries; as in the case of false statements about the defendant's own products which enable it to steal market share from competitors. In such cases the distributive application of the laws of the various markets involved to the harms directly sustained in each country seems especially likely to give rise to complexity and confusion.

Article 6(3) of the Rome II Regulation, in dealing with tortious restrictions of competition, refers to the law of the country where the market is, or is likely to be, affected. It does, however, provide an exception enabling a plaintiff who sues at the defendant's domicile to invoke exclusively the law of that country, where the market is, or is likely to be, affected in more than one country, and the market in the Member State of the defendant's domicile is among those directly and substantially affected. Insofar as this proviso is not applicable, Article 6(3) appears to contemplate distributive application of the laws of the various markets directly affected. Again this could give rise to particular complexity and confusion in cases involving Internet activities; for example, where the claim is against a supplier of electronic services for discriminatory treatment of customers.

In contrast, as regards the infringement of national intellectual property rights, Article 8 simply refers to the law of the country for which protection is claimed, and Article 13 extends this rule to restitutionary (as well as tortious) claims.

Claims for defamation or invasion of privacy are excluded from the scope of the Regulation by Article $1(2)(\mathrm{g})$, and thus are in general governed by the law identified in accordance with the conflict rules of

43 See the Explanatory Memorandum accompanying the EC Commission Proposal of 22nd July 2003, $\operatorname{COM(2003)~} 427$ final, at p. 16. 
the forum country. Thus the ruling in eDate Advertising $v X$ and Martinez $v M G N^{44}$ on the operation of Article 7(2) of the Brussels I Regulation will not necessarily have any influence on choice of law for these torts.

\section{The Directive on Electronic Commerce}

Article 27 of the Rome II Regulation specifies that the Regulation is not to prejudice the application of provisions of European Union law which, in relation to particular matters, lay down conflict rules relating to non-contractual obligations, and Recital 35 declares that the Regulation should not prejudice the application of other instruments laying down provisions designed to contribute to the proper functioning of the internal market, insofar as they cannot be applied in conjunction with the law designated by the rules of the Regulation; and that the application of provisions of the applicable law designated by the rules of the Regulation should not restrict the free movement of goods and services as regulated by European Union instruments, such as EC Directive 2000/31 on Electronic Commerce. ${ }^{45}$

The Directive on Electronic Commerce, by Article 3(1), requires each Member State to ensure that the information society services provided by a service provider established on its territory comply with the national provisions applicable in the Member State in question which fall within the co-ordinated field. Article 3(2) prohibits Member States, for reasons falling within the co-ordinated field, from restricting the freedom to provide information society services from another Member State. Article 1(4) specifies that the Directive does not establish additional rules on private international law, but Recital 23 adds that provisions of the applicable law designated by rules of private international law must not restrict the freedom to provide information society services as established in the Directive.

The effect of the Directive on choice of law in tort was addressed by the European Court in eDate Advertising $v \mathrm{X}$ and Martinez $v M G N,{ }^{46}$ which involved an action for invasion of privacy brought in a German

44 Joined Cases C-509/09 and C-161/10, [2011] ECR I-10269. See pp. 13-14 above.

45 [2000] OJ L178/1.

46 Joined Cases C-509/09 and C-161/10, [2011] ECR I-10269. See also Case C-292/10: $G$ v De Visser [2013] QB 168, where the European Court ruled that Article 3 of the Directive does not apply to a situation where the place of establishment of the information society service provider is unknown, since its application is subject to identification of the Member State in whose territory the service provider in question is actually established. 
court by a German plaintiff against an Austrian defendant in respect of a publication on the defendant's website (in the .at top-level domain). It seems that liability existed under Austrian law, but not under German law. The European Court ruled that, although Article 3 of the Directive does not require transposition in the form of a specific conflict rule, it does require that, in relation to the co-ordinated field, Member States must ensure that the provider of an electronic commerce service is not made subject to stricter requirements than those provided for by the substantive law applicable in the Member State in which the service provider is established. It explained that Article 3 extends to the private law field, and that Article 3 is not in the nature of a conflict rule designed to resolve a specific conflict between several laws which may be applicable, but merely serves as a corrective, designed to facilitate the internal market, to the conflict rules otherwise applicable.

Although the eDate ruling involved a tort claim for invasion of privacy, which was therefore excluded from the scope of the Rome II Regulation by Article 1(2)(g), it seems impossible to avoid the conclusion that the admission of the home-country principle established by the Directive for Internet service providers into the sphere of civil claims for tort will extend to other torts to which the Regulation does apply, with the exception of claims for infringement of intellectual property rights, which are excluded from Article 3 of the Directive by Article 3(3) and the Annex thereof. On the other hand, it seems clear that EC Directive 2006/123 on Services in the Internal Market ${ }^{47}$ cannot affect choice of law in respect of torts, in view of Recital 90 and Articles 3(2) and 17(5) of that Directive.

It seems difficult to regard the intrusion of the home-country principle, utilised by the Directive on Electronic Commerce, into the sphere of choice of law in tort, generally governed by the Rome II Regulation, as other than an unprincipled distortion of the careful balance of interests achieved by the Regulation, so as to provide an entirely undeserved advantage to a well-resourced and noisy lobby.

\section{RESTITUTIONARY CLAIMS}

As regards judicial jurisdiction, Article 7(2) of the Brussels I Regulation extends to autonomous restitutionary claims for unjust enrichment, which are not necessarily based on a wrongful act by the defendant and which

47 [2006] OJ L376/36. 
are either unconnected with any contract or arise from the initial invalidity or illegality of a contract. ${ }^{48}$ Thus it seems that the reference in Article 7(2) to the harmful event must be read analogistically, as referring to an event equivalent or corresponding to a harmful event, so that jurisdiction is conferred both on the courts for the place of the transfer (the movement of the benefit away from the plaintiff), and on those for the place of the enrichment (the initial receipt of the benefit by the defendant). The identification of these places could give rise to difficulty where a payment is made to or from an online bank account. Presumably, as in the case of tortious claims, one could regard an online bank account as located at the office of the bank by which the online banking service is administered.

As regards choice of law, the Rome II Regulation extends to restitutionary claims for unjust enrichment or arising from unauthorised agency. Problems in relation to Internet activities may arise from the reference, by Article 10(3), of certain claims for unjust enrichment to the law of the country in which the unjust enrichment took place. It seems clear that for this purpose an enrichment takes place where the relevant benefit is initially received by the defendant. Thus problems in identifying the place could arise where, for example, a sum is paid into an online bank account. Presumably one could again regard an online bank account as located at the office of the bank by which the online banking service is administered.

Choice of law problems in relation to Internet activities could also arise from the reference, in Article 11(3) of the Rome II Regulation, in relation to certain claims arising from an act of unauthorised agency, to the law of the country in which the unauthorised act was performed; as where the plaintiff's intervention takes the form of an email communication (for example, informing an authority of the existence of a dangerous fire, likely to destroy property located on both sides of a national border). Since the provision is designed to refer to the place where the plaintiff acted, it may be taken to refer to the place from which the plaintiff sent the email, rather than the place where it was received.

48 See Case 189/87: Kalfelis v Schröder [1988] ECR 5565. 